\title{
Atrophic vaginitis: symptoms, diagnosis and treatment
}

\section{Zanikowe zapalenie pochwy: objawy, diagnostyka i leczenie}

\author{
Mirosław Wielgoś, Natalia Mazanowska, Bronisława Pietrzak \\ $1^{\text {st }}$ Chair and Department of Obstetrics and Gynecology, Medical University of Warsaw; \\ Head of Department: Prof. Mirosław Wielgoś MD, PhD
}

Przegląd Menopauzalny 2013; 17 (5): 434-437

\section{Summary}

Improvement of living conditions and advances in medicine throughout the last few decades have led to prolonged life expectancy. Unfortunately, inevitable physiological processes of ageing cause burdensome changes responsible for worsening of the quality of life of postmenopausal women. Many of these changes are linked to the loss of ovarian hormonal activity. Complaints resulting from a decline in the estrogen level and symptoms involving the lower genitourinary tract in postmenopausal women usually progress with time. They emerge from loss of vaginal epithelium thickness and elasticity, increase in $\mathrm{pH}$ of vaginal discharge as well as shift from physiological vaginal microflora with prevailing Lactobacillus spp. to abnormal milieu with dominance of other frequently anaerobic microorganisms. To relieve often severe symptoms of urogenital atrophic changes non-hormonal as well as hormonal treatment methods are available. Vaginal moisturizers and lubricants as well as systemic hormone therapy are treatment options to be considered. Local estrogen therapy remains the first choice therapy in women with no contraindications to estrogen administration. It is an effective and safe method of relieving symptoms of urogenital atrophy. There are different preparations of estrogens for local therapy available. A combination of estrogen and Lactobacillus cultures is an option worth considering. Early treatment allows for maintaining healthy vaginal microflora, which prevents development of distressing symptoms that decrease the quality of life.

Key words: atrophic vaginitis, postmenopause, local estrogen therapy, vaginal microflora.

\section{Streszczenie}

Postęp medycyny oraz poprawa warunków życia w ciągu ostatnich dziesięcioleci spowodowały wydłużenie przeciętnej długości życia. Nieuchronne procesy fizjologiczne związane ze starzeniem pogarszają jakość życia kobiet po menopauzie. Wiele z objawów związanych jest z zanikiem czynności hormonalnej gonad. Wynikające z tego objawy atrofii w obrębie dolnego odcinka dróg moczowo-płciowych u kobiet w wieku pomenopauzalnym zazwyczaj pogłębiają się w miarę upływu czasu. Wiążą się one z wynikającym z niedoboru estrogenów scieńczeniem i utratą elastyczności nabłonka pochwy, wzrostem odczynu pH i zastąpieniem fizjologicznej flory, jaką stanowią pałeczki kwasu mlekowego przez inne bakterie, często z przewagą beztlenowców. W chwili obecnej w łagodzeniu i leczeniu dolegliwości związanych z atrofią urogenitalną dysponujemy zarówno niehormonalnymi, jak i hormonalnymi metodami leczenia. Zastosowanie znajdują preparaty nawilżające i lubrykanty, a także systemowa terapia hormonalna. Leczeniem pierwszego wyboru u kobiet bez przeciwwskazań do terapii estrogenowej pozostaje miejscowe zastosowanie estrogenów. Stanowi ono skuteczną i bezpieczną metodę leczenia uciążliwych objawów atrofii urogenitalnej u kobiet. Na rynku dostępne są różne preparaty do miejscowej terapii estrogenowej. Wartą rozważenia opcją terapeutyczną jest zastosowanie preparatów estrogenów w kombinacji ze szczepami Lactobacillus. Odpowiednio wcześnie rozpoczęta terapia oraz zastosowanie dawek podtrzymujących pozwala na utrzymanie prawidłowego mikrośrodowiska w pochwie, co zapobiega rozwojowi uciążliwych objawów istotnie pogarszających jakość życia.

Słowa kluczowe: zanikowe zapalenie pochwy, postmenopauza, miejscowa terapia estrogenowa, mikroflora pochwy.

Address for correspondence:

Prof. Mirosław Wielgoś, Pl. Starynkiewicza 1/3, 02-015 Warszawa, Poland, tel. +48 22502 14 30, e-mail: miroslaw.wielgos@wum.edu.pl 


\section{Introduction}

Throughout the last few decades, improvement of living conditions and advances in medicine have led to prolonged life expectancy. A small or even negative population growth rate observed in the majority of developed countries means that the share of elderly people in the ageing general population significantly increases with a high prevalence of postmenopausal women. They are often fully physically and mentally fit and wish to lead an active lifestyle.

Inevitable physiological processes of ageing unfortunately cause burdensome changes responsible for worsening of the quality of life. Many of them are linked to the loss of ovarian hormonal activity. Main complaints in postmenopausal women are vasomotor symptoms and urogenital atrophy resulting from a decline in the estrogen level. Whereas vasomotor symptoms tend to resolve with age, urogenital atrophy typically develops later in life and is often progressive. The lack of estradiol proproliferative effect on the epithelium of the vagina, urethra as well as the lower part of the cervix is noticeable in every third female in perimenopause and over $50 \%$ of postmenopausal women [1].

\section{Influence of estrogens on vaginal milieu}

In the premenopausal state, vaginal epithelium is influenced by high estradiol levels, stimulating cell maturation up to the superficial layer. Superficial epithelial cells continuously exfoliate and die, releasing glycogen, that breaks down to glucose. Glucose is metabolised by species of Lactobacillus to lactic acid and $\mathrm{H}_{2} \mathrm{O}_{2}$, which allows for maintaining of normal vaginal microflora. The coexistence of estrogenic activity and Lactobacilli leads to acidic vaginal pH 3.5-4.5, which mechanism in a healthy female of reproductive age prevents urogenital infections [2-4].

Postmenopausal decline in the estrogen level leads to impairment of blood flow in the lower genitourinary tract, decrease in vaginal discharge as well as deterioration of connective tissue metabolism which negatively influences vaginal elasticity. The vaginal exam reveals smooth, pale, thinned mucosa prone to injuries and bleeding with minimal trauma. Lack of maturation of epithelial cells and thinning of the superficial layer rich in glycogen disturbs the normal vaginal microflora. The loss of Lactobacilli suppresses production of lactic acid which results in the increase in vaginal $\mathrm{pH}$ and development of abnormal microflora. In consequence, increased susceptibility to infections with bacteria migrating from the vulvar and perianal region is observed. Clinical symptoms constellation connected with postmenopausal decreased estrogenization of vulvovaginal mucosa may be described as atrophic vaginitis, vaginal atrophy or urogenital atrophy.

\section{Diagnosis of atrophic vaginitis}

The most common complaints and symptoms in patients with atrophic vaginitis according to Lynch et al. are [3]:

- vaginal dryness (in 3-5\% of females of reproductive age and in 30-50\% of postmenopausal women),

- vulvovaginal irritation: pruritus, burning; redness and petechiae in the case of accompanying inflammation,

- dyspareunia: pain and burning on sexual intercourse,

- yellow or purulent discharge,

- malodor, which is a bacterial vaginosis (BV) symptom. The development of BV is caused by the decrease in Lactobacilli and colonisation of the lower genitourinary tract by anaerobes: Gardnerella vaginalis, Prevotella spp., Mobiluncus spp., Atopobium vaginae.

The above-mentioned symptoms may be accompanied by lower urinary tract complaints. Atrophic changes of structures derived from embryonic urogenital sinus result in dysuric symptoms, bladder overactivity, stress incontinence and recurrent urinary tract infections.

Clinical findings include sparse pubic hair, atrophy of labia majora and minora, narrowing of vaginal introitus and decrease in length and width of the vagina. Other symptoms include decreased or abnormal vaginal discharge, thinning and paleness of vaginal epithelium, smoothing and reduced elasticity of the vulvovaginal mucosa, rectocele, uterine prolapse, reddened inflamed vulvar skin with fissures.

Laboratory tests reveal a low serum estradiol level (<30 pg/l) and cytological smear shows a lower percentage of superficial cells with the dominance of parabasal cells. Objective tests evaluating the effect of estrogen on vaginal tissue are: vaginal $\mathrm{pH}$ measurement and cell maturation index assessed in smear taken from the lateral vaginal wall. Vaginal $\mathrm{pH}>4.6$ with no signs of BV indicates vaginal atrophy. Vaginal maturation index evaluates the percentage of superficial, intermediate and parabasal epithelial cell types. In premenopausal women, there is over $15 \%$ of superficial cells, whereas in postmenopause the percentage is less than $5 \%$. In clinical practice, the vaginal maturation index is rarely performed, mainly because of lack of necessary laboratory devices and experienced staff [2]. Microbiological evaluation of vaginal discharge often reveals presence of bacterial infection $[5,6]$.

Atrophic vaginitis is more commonly encountered in obese and diabetic females. It should be noted that loss of endogenous estrogen production may result from immunologic disorders, radio- and chemotherapy as well as surgical castration. Besides, low estrogen levels are encountered typically in the postpartum and breastfeeding period as well as in the case of pharmacological therapy of endometriosis and uterine fibroids [7].

Atrophic vaginitis is a chronic condition and symptoms worsen with time since menopause. It leads to de- 
terioration of quality of life resulting from physical discomfort, sexual disorders and severe emotional distress.

\section{Treatment options}

\section{Non-hormonal preparations}

In females who choose the non-hormonal treatment option or have contraindications to estrogen use, vaginal moisturizers and lubricants are helpful in symptomatic atrophic vaginitis. They relieve vaginal symptoms such as itching and irritation by means of restoring vaginal $\mathrm{pH}$ and moisture. They allow for regular sexual activity which maintains proper elasticity and pliability of the vagina. There are also reports on vaginal moisture improvement with use of vitamin E or D preparations.

\section{Systemic hormone therapy}

Exogenous estrogen used in systemic HT restores vaginal epithelium and vascularization, improves its moistness and sinks $\mathrm{pH}$ level. According to published reports, it relieves vaginal symptoms in $75 \%$ of women with atrophic vaginitis. It was noted that hormonal therapy with an addition of topical estrogen improves vaginal symptoms more efficiently than HT itself [1]. Systemic hormone therapy is not recommended in females with isolated vaginal symptoms.

\section{Local estrogen therapy [8]}

In the absence of systemic menopausal complaints, local estrogen therapy is a preferable and efficacious method of chronic atrophic vaginitis treatment.

Vaginal symptoms quickly resolve on local estrogen therapy. The superficial epithelium layer thickens, vaginal blood flow improves and so does vaginal $\mathrm{pH}$. Similar processes are observed in the lower urinary tract. International societies published EBM guidelines suggesting that in females with urogenital atrophy without contraindications to estrogen use, the local therapy with low dose estrogen is a treatment of choice. Tissues of the lower genitourinary tract are highly responsive to the pro-proliferative effect of low dose estrogen preparations because of greater, in comparison to uterus, sensitivity of estrogen receptors. Typically, no systemic effects of local estrogen therapy are observed.

Preparations used in local estrogen therapy are available in several forms (tablets, pessaries, cream, vaginal rings) containing conjugated estrogens, estradiol, estriol or estrone. Local estrogen therapy effect is observed after 4-6 weeks in $80-90 \%$ of patients. The treatment is well tolerated even in the case of prolonged use, although there are sparse data on safety of long-term therapy [9].
Available preparations in topical estrogen therapy:

- vaginal rings: placed vaginally every 3 months, delivering $17 \beta$-estradiol or estradiol acetate. Not available in Poland,

- vaginal estrogen tablets: containing $25 \mu$ g of $17 \beta$-estradiol or $0.5 \mathrm{mg}$ of estriol.

According to published data, they not only relieve vaginal atrophy but also improve vasomotor symptoms.

- Conjugated estrogens (CEE) vaginal creams contain 0.3-0.625 mg of conjugated estrogens: estrone and $17 \beta$-estradiol in a single dose. Highest systemic absorption of those preparations, with a higher estradiol and lower FSH serum level, was observed. There were cases of endometrial proliferation and uterine bleeding on CEE therapy, so it is less acceptable in vaginal atrophy treatment.

- Preparations of estriol with Lactobacillus cultures.

According to the majority of international societies, estriol is the most preferable and effective estrogen in vaginal symptoms treatment. It is produced in the liver as $17 \beta$-estradiol metabolite and has relatively low systemic estrogenic activity. However, it exerts a specific cytotropic effect on tissues developing from embryonic genitourinary sinus. As estriol derives from estradiol and estrone metabolism, therapy with this hormone does not affect serum estradiol and estrone levels. Excretion of estriol occurs via urine in inactive forms of glucuronates and sulphates. Especially favorable outcomes of atrophic vaginitis treatment are observed with the use of estriol combined with Lactobacilli cultures. Lactobacilli, prevailing in healthy vaginal microflora, have a significant impact on vaginal ecosystem through lactic acid and $\mathrm{H}_{2} \mathrm{O}_{2}$ production. Estriol with Lactobacilli combination optimizes immunologic mechanisms responsible for detection and fighting infections of the urogenital tract. Mucosal secretion of secretoglobin $1 \mathrm{D}$ and $2 \mathrm{~A}$ increases thanks to higher activity of respective genes transcription. Similarly, the rise of lactoferrin gene activity is observed. Lactoferrin is a protein playing an important role in regulation of immunologic response of mucosae to bacterial infection. Another favorable mechanism is activation of interleukin-1 gene. Interleukin-1 regulates immunologic response in vaginal mucosa (leukocyte migration, gene expression, inflammation) that inhibits pathogenic bacteria proliferation. Lactobacilli in vaginal milieu, in the presence of estriol, reinitiate their metabolism and lower vaginal $\mathrm{pH}$ within few hours. It leads to quick re-establishment of normal vaginal milieu and recline of abnormal microflora symptoms (most frequently bacterial vaginosis).

Estriol administered in the ultra-low dose prevents a typical side effect of estrogen therapy such as endometrial proliferation. Numerous studies proved that the ultra-low dose of estriol $(0.03 \mathrm{mg}$ ) combined with Lactobacilli administered vaginally relieved vaginal atrophy symptoms and re-established normal vaginal 
microflora with the same efficacy as $0.05 \mathrm{mg}$ of estradiol. At the same time, there are no reports of endometrial proliferation or increased risk of endometrial hyperplasia. The expected effect is achieved in 80-90\% of females after 3 weeks' therapy, in some cases after 4-6 weeks. To maintain the effect of treatment and avoid frequent recurrence, typically in 6 months after termination of therapy, it is suggested to administer a maintenance dose 1-2 times a week [10-12].

Local therapy was also proven effective in overactive bladder in postmenopausal women and after urogynecological incontinence surgeries. The treatment is recommended for urogynecological complaints, although not only estrogen deficiency is responsible for their occurrence. It has a favourable effect in women with recurrent urinary tract infections after menopause. In the Cochrane meta-analysis published in 2008 (9 clinical studies including 3345 women), it was demonstrated that vaginal therapy with estriol decreases frequency of lower urinary tract infections more efficiently than oral estrogen therapy. Better outcomes of surgical incontinence/prolapse treatment have been reported by many authors after local vaginal estrogen therapy $[5,6,13]$.

The Polish Menopause and Andropause Society in 2011 published recommendations on local estrogen therapy in postmenopausal women, listing indications to therapy [14]:

- dyspareunia resulting from vaginal dryness,

- urge incontinence in patients with vaginal atrophy,

- perioperative therapy in patients undergoing surgery because of genital prolapse,

- additional therapy to pelvic floor exercises.

\section{The safety of local estrogen therapy}

Local estrogen therapy led for 12-24 months is relatively safe. It is believed that it does not require endometrial protection by addition of gestagens. The possibility of overdose leading to systemic side effects and endometrial proliferation and hyperplasia should nevertheless be remembered. Currently, the exact influence of local estrogen therapy on development or recurrence of breast cancer is not known. There are study results suggesting that estriol administered in high doses may stimulate estrogen receptors in breast and endometrial tissue. So far there are no guidelines regarding duration of local estrogen therapy and ultralow dose of estrogen is recommended. There are only sparse data regarding safety of local estrogen therapy in atrophic vaginitis in females with endometrial cancer and therefore use of topical estrogens is advisable only in individual cases after weighing up risks and benefits of the therapy and after consultation with the oncologists $[1,13,15]$.

\section{Conclusions}

Local estrogen therapy of atrophic vaginitis is a simple and safe treatment leading to improvement of the quality of life. The treatment should be commenced early, before irreversible atrophic changes develop. Early local therapy may prevent urogynecological complaints occurrence. It should be continued as maintenance therapy in order to maintain healthy vaginal ecosystem. Release of symptoms may be achieved by means of vaginal moisturizers and lubricants. Recently there have been trials analyzing use of progestagens, androgens (dehydroepiandrosterone - DHAES) and agonists and antagonists of estrogen receptors [16].

\section{The authors declare no conflict of interests.}

\section{References}

1. Sturdee DW, Panay N; International Menopause Society Writing Group. Recommendations for the management of postmenopausal vaginal atrophy. Climacteric 2010; 13: 509-22.

2. Mac Bride MB, Rhodes DJ, Shuster LT. Vulvovaginal atrophy. Mayo Clin Proc 2010; 85: 87-94.

3. Lynch C. Vaginal estrogen therapy for the treatment of atrophic vaginitis. J Womens Health 2010; 8: 1595-606.

4. Aroutcheva A, Gariti D, Simon M, et al. Defense factors of vaginal lactobacilli. Am J Obstet Gynecol 2001; 185: 375-9.

5. Stachowiak G, Pertyński T. Kliniczne aspekty atrofii urogenitalnej u kobiet. Przegl Menopauz 2011; 15: 1-4.

6. Wilamowska A, Woźniak P, Stetkiewicz T, et al. Biocenoza pochwy u kobiet po menopauzie. Przegl Menopauz 2011; 15: 469-72.

7. Tomaszewski J. Estrogenoterapia dopochwowa - czy tylko dla kobiet po menopauzie? Przegl Menopauz 2008; 12: 158-67.

8. Hohenhaus MH. Vulvovaginal atrophy: a common - and commonly overlooked - problem. Med Health R I 2011; 94: 138-40.

9. Jaisamrarn U, Triratanachat S, Chaikittisilpa S, et al. Ultra-low-dose estriol and lactobacilli in the local treatment of postmenopausal vaginal atrophy. Climacteric 2013; 16: 1-9.

10. Griessera H, Skonietzki S, Fischer T, et al. Low dose estriol pessaries for the treatment of vaginal atrophy: A double-blind placebo-controlled trial investigating the efficacy of pessaries containing $0.2 \mathrm{mg}$ and $0.03 \mathrm{mg}$ estriol. Maturitas 2012; 71: 360-8.

11. Buhling KJ, Eydeler U, Borregaard S, et al. Systemic bioavailability of estriol following single and repeated vaginal administration of $0.03 \mathrm{mg}$ estriol containing pessaries. Arzneimittelforschung 2012; 62: 378-83.

12. The North American Menopause Society. The 2012 hormone therapy position statement of the North American Menopause Society. Menopause 2012; 19: 257-71.

13. Kokot-Kierepa M, Bartuzi A, Kulik-Rechberger B, et al. Lokalna terapia estrogenowa - implikacje kliniczne - 2012 update. Ginekol Pol 2012; 83: 772-3.

14. Rekomendacje Polskiego Towarzystwa Menopauzy i Andropauzy dotyczące stosowania lokalnej terapii hormonalnej u kobiet w okresie menopauzy. Przegl Menopauz 2011; 15: 263-6.

15. Neven P, Donders G, Mogele M, et al. Ultra-low dose vaginal estriol and Lactobacillus acidophilus (Gynoflor ${ }^{\circledR}$ ) in early breast cancer survivors on aromatase inhibitors: Pharmacokinetic, efficacy and safety results from a phase I study. Cancer Res 2012; 72 Suppl. 3: 2.

16. Panjari M, Davis SR. Vaginal DHEA to treat menopause related atrophy: A review of the evidence. Maturitas 2011; 70: 22-5. 